Gut, 1982, 23, 766-769

\title{
Enumeration of lymphocyte populations defined by surface markers in the whole blood of patients with Crohn's disease
}

\author{
ELIZABETH O PEPYS, ELIZABETH A FAGAN, GLENYS A TENNENT, \\ V S CHADWICK, and M B PEPYS
}

From the Immunological Medicine and Gastroenterology Units, Department of Medicine, Royal Postgraduate Medical School, London

SUMMARY The proportions and absolute numbers of different lymphocyte populations were determined using alkaline phosphatase-labelled reagents in the whole peripheral blood of 22 patients with Crohn's disease. Monoclonal mouse anti-T cell antibody (OKT3) was used to identify $\mathrm{T}$ cells, polyvalent $\mathrm{F}\left(\mathrm{ab}^{\prime}\right)_{2}$ anti-human immunoglobulin for $\mathrm{B}$ cells, $\mathrm{C} 3 \mathrm{~b}$ for $\mathrm{C} 3 \mathrm{~b}$-receptor bearing cells, and soluble IgG antibody-antigen complexes for $\mathrm{Fc}(\gamma)$-receptor bearing cells. Endogenous myeloperoxidase served to distinguish monocytes. Application of this methodology to whole blood avoids the inevitable loss of cells which accompanies separation of mononuclear cells from blood and therefore permits precise enumeration of lymphocyte populations in the circulation. No significant difference from healthy adult controls was observed in any of the lymphocyte subsets tested.

The cause and pathogenesis of Crohn's disease are not known but the inflammatory infiltrate in lesions of the disease, consisting of $\mathrm{T}$ lymphocytes, B lymphocytes, plasma cells, macrophages, and granulomata, ${ }^{12}$ suggests that immunological mechanisms may be involved. There is, however, controversy in the literature regarding the in vivo immunocompetence of patients with Crohn's disease and the proportions, numbers and functional activity of their peripheral blood lymphocyte populations tested in vitro. ${ }^{13-25}$ All the in vitro studies have been performed on preparations of mononuclear cells isolated from peripheral blood. There is no procedure for such isolation that recovers all the mononuclear cells and it is well established that with yields of less than $70 \%$ there is appreciable distortion of the relative proportions of $\mathrm{T}$ and $\mathrm{B}$ lymphocytes, ${ }^{26}$ and possibly of subsets within these populations. These distortions make it impossible to extrapolate back to the true proportions and thence to the absolute numbers of different lymphocyte populations in the circulation in vivo, which is the clinically relevant information. Some authors, realising the significance of pre-

Received for publication 18 January 1982 sentation of the absolute values, have calculated them but, in the absence of results detailing lymphocyte yields over $70 \%$, these calculations are not valid. Such high yields are particularly difficult to achieve from the blood of individuals with active inflammatory disease.

Another important problem in enumerating circulating lymphocyte populations is the distinction between lymphocytes and monocytes. The latter share some surface phenotypic properties with lymphocytes, they are very difficult to eliminate completely from lymphocyte preparations, and procedures for their elimination generally cause differential loss of $\mathrm{T}$ and $\mathrm{B}$ cells. ${ }^{26}$

In order to overcome these problems we have developed methods for identification of lymphocyte surface markers in whole peripheral blood under conditions in which there is no loss of cells. ${ }^{26-28}$ Positive cytochemical identification of monocytes by staining for myeloperoxidase enables them to be excluded from the counts and lymphocyte surface markers are identified using alkaline phosphataselabelled reagents. ${ }^{29} 30$ The use of immunoenzyme staining also provides a greatly enhanced sensitivity for detection of some markers, particularly surface immunoglobulin. ${ }^{31}$ This has recently enabled us to confirm $^{31}$ the observations of Haegert and Coombs ${ }^{32}$ 
that the so-called non-B, non-T or 'null' cells in normal peripheral blood are in fact $B$ cells (B-minor cells) which express much lower levels of intrinsic immunoglobulin on their surface than do the classical B cells (B-major cells).

We have now applied this methodology to the precise quantification of peripheral blood lymphocyte populations in patients with Crohn's disease and report here that the proportions and the absolute numbers of $\mathrm{T}$ cells, B-major and B-minor cells, $\mathrm{Fc}(\gamma)$ and $\mathrm{C} 3 \mathrm{~b}$-receptor cells were not significantly different from normal.

\section{Methods}

\section{PATIENTS}

Twenty-two patients were studied in whom the diagnosis of Crohn's disease was established on the basis of standard clinical, radiological, and histopathological features, the latter according to the criteria of Lockhart-Mummery and Morson. ${ }^{133} 34$ There were 15 male and seven female patients with a mean age of 41 years (range 25-78 years). The site of disease at the time of study was the ileum in eight, the colon in six, and ileocolonic in eight. Nine individuals had had bowel resections in the past. At the time when blood was taken for lymphocyte studies, samples were also obtained for measurement of serum $\mathrm{C}$-reactive protein, and the patients were assessed for calculation of the Crohn's disease activity index. ${ }^{35}$ The C-reactive protein levels were measured by electroimmunoassay as described previously. ${ }^{36}{ }^{37}$ Healthy adult hospital .staff served as controls and one was included in each run of Crohn's disease patients.

Venous blood anticoagulated with EDTA was processed for the alkaline phosphatase-whole blood method precisely as described before. ${ }^{29-31} \mathrm{~T}$ cells were detected using a monoclonal mouse antibody (OKT3, Ortho Pharmaceutical Ltd, High Wycombe, Bucks., England) reactive with all human peripheral blood $\mathrm{T}$ cells. ${ }^{38} \mathrm{~B}$-major and B-minor cells and lymphocytes bearing receptors for $\mathrm{Fc}(\gamma)$ and for $\mathrm{C} 3 \mathrm{~b}$ were detected using the same reagents and methods as before. ${ }^{30} 31$ All the antiimmunoglobulin reagents and the anti-C3 antibody were pepsin $F\left(a b^{\prime}\right)_{2}$ fragments of IgG. The proportion and absolute number of each lymphocyte population defined by a particular surface marker were calculated and are shown in the results.

\section{Results}

The percentages and absolute numbers in whole blood of the different lymphocyte populations defined by the various surface markers tested are shown in Tables 1 and 2. There was no significant difference between the whole group of Crohn's disease patients and the control group for any of the markers. The results in patients with active disease were also compared with those in patients with quiescent disease. Two separate analyses were performed, one with Crohn's disease activity index values greater than 149 as the criterion of activity, the other on the basis of serum C-reactive protein concentrations greater than $29 \mathrm{mg} / \mathrm{l}$ (Table 3). In neither case were there any significant differences. There was a wider range of total lymphocyte counts in the patient group and therefore more variation in the absolute numbers of the various lymphocyte subsets but there were no significant differences from the controls.

\section{Discussion}

The patients studied here were well characterised in terms of the extent and activity of their disease, and included a spectrum of disease activity from quiescent to very active. Using a precise and sensitive method for detection and enumeration of different lymphocyte populations, which avoids the pitfalls of the techniques used in earlier studies, we

Table 1 Lymphocyte populations identified by surface markers (percentage of total lymphocytes)

\begin{tabular}{|c|c|c|c|c|c|c|c|c|}
\hline \multirow[b]{2}{*}{ Surface marker } & \multicolumn{4}{|c|}{ Crohn's disease } & \multicolumn{4}{|c|}{ Normal controls } \\
\hline & Mean & $S D$ & Range & No. & Mean & $S D$ & Range & No. \\
\hline $\begin{array}{l}\text { OKT3 positive ( } \mathrm{T} \text { cells) } \\
\text { Surface membrane immunoglobulin }\end{array}$ & $78 \cdot 2$ & $7 \cdot 2$ & $67 \cdot 0-91 \cdot 0$ & 18 & $79 \cdot 5$ & $6 \cdot 8$ & $67 \cdot 3-88 \cdot 0$ & 8 \\
\hline $\begin{array}{l}\text { detected directly (B-major cells) } \\
\text { Surface membrane immunoglobulin } \\
\text { detected with enhanced sensitivity }\end{array}$ & $15 \cdot 5$ & $8 \cdot 1$ & $5 \cdot 0-31 \cdot 6$ & 22 & $14 \cdot 3$ & $6 \cdot 1$ & $7 \cdot 0-27 \cdot 8$ & 10 \\
\hline (B-major + B-minor cells) & $22 \cdot 3$ & $8 \cdot 8$ & $13 \cdot 0-34 \cdot 0$ & 7 & $24 \cdot 0$ & $2 \cdot 8$ & $20 \cdot 9-27 \cdot 5$ & 4 \\
\hline Sum of $T$ cells + all B cells & $97 \cdot 3$ & $8 \cdot 1$ & $81 \cdot 0-104 \cdot 8$ & 7 & $99 \cdot 3$ & 5.9 & $93 \cdot 9-107 \cdot 8$ & 4 \\
\hline C3b-receptor & $6 \cdot 2$ & $3 \cdot 1$ & $2 \cdot 0-13 \cdot 7$ & 22 & 7.9 & 3.0 & $4 \cdot 0-11 \cdot 8$ & 10 \\
\hline $\mathrm{Fc}(\gamma)$-receptor & $6 \cdot 0$ & 4.4 & $1 \cdot 0-17 \cdot 7$ & 22 & $8 \cdot 0$ & $2 \cdot 2$ & $5 \cdot 0-10.9$ & 10 \\
\hline
\end{tabular}


Table 2 Lymphocyte populations identified by surface markers (absolute numbers $\left.\left(\times 10^{6} / l\right)\right)$

\begin{tabular}{|c|c|c|c|c|c|c|c|c|}
\hline \multirow[b]{2}{*}{ Surface marker } & \multicolumn{4}{|c|}{ Crohn's disease } & \multicolumn{4}{|c|}{ Normal controls } \\
\hline & Mean & $S D$ & Range & No. & Mean & $S D$ & Range & No. \\
\hline Total lymphocyte count & 3248 & 1521 & $1209-7500$ & 22 & 2297 & 610 & $1400-3383$ & 10 \\
\hline OKT3 positive ( $\mathrm{T}$ cells) & 2392 & 1078 & $968-4608$ & 18 & 1776 & 452 & $1167-2353$ & 8 \\
\hline $\begin{array}{l}\text { Surface membrane immunoglobulin } \\
\text { detected directly (B-major cells) }\end{array}$ & 482 & 281 & $89-1191$ & 22 & 352 & 226 & $197-939$ & 10 \\
\hline $\begin{array}{l}\text { Surface membrane immunoglobulin } \\
\text { detected with enhanced sensitivity }\end{array}$ & & & & & & & & \\
\hline (B-major + B-minor cells) & 790 & 335 & $231-1280$ & 7 & 553 & 208 & $349-818$ & 4 \\
\hline C3b-receptor & 189 & 111 & $35-449$ & 22 & 180 & 68 & $56-282$ & 10 \\
\hline $\mathrm{Fc}(\gamma)$-receptor & 172 & 122 & $23-526$ & 22 & 180 & 64 & $80-285$ & 10 \\
\hline
\end{tabular}

Table 3 Classification of patients with Crohn's disease according to indices of disease activity

\begin{tabular}{|c|c|c|c|c|c|c|c|c|}
\hline & \multicolumn{4}{|c|}{ Crohn's disease activity index (score) } & \multicolumn{4}{|c|}{$C$-reactive protein $(\mathrm{mg} / \mathrm{l})$} \\
\hline & Criterion & Median & Range & No. & Criterion & Median & Range & No. \\
\hline $\begin{array}{l}\text { Active } \\
\text { Quiescent }\end{array}$ & $\begin{array}{l}\geqslant 150 \\
<150\end{array}$ & $\begin{array}{r}188 \\
51\end{array}$ & $\begin{array}{r}150-342 \\
25-140\end{array}$ & $\begin{array}{r}7 \\
15\end{array}$ & $\begin{array}{l}\geqslant 30 \\
<30\end{array}$ & $\begin{array}{r}43 \\
7\end{array}$ & $\begin{array}{c}36-112 \\
0-27\end{array}$ & $\begin{array}{r}8 \\
14\end{array}$ \\
\hline
\end{tabular}

were unable to find any difference from normal in the proportions or absolute numbers of $T$ lymphocytes, B-major or B-minor cells, $\mathrm{Fc}(\gamma)$ or C3b-receptor bearing lymphocytes.

These results do not exclude the possibility that individuals with Crohn's disease may have abnormalities among their circulating lymphocytes, but they do show that any such abnormality must be subtle and does not disturb the distribution of the main lymphocyte phenotypes.

It has been suggested that there may be an imbalance of helper and suppressor $\mathrm{T}$ cells in this disease $^{22} 25$ but the tests used to arrive at this conclusion have been performed on separated mononuclear cell preparations. Furthermore, there is now evidence that some of the so-called T $\gamma$ cells, which were characterised as the $T$ suppressor population, are actually monocytes. ${ }^{39} 40$ If abnormalities of $T$ cell subsets do exist, a more accurate and reliable way to demonstrate them may be to use the monoclonal antibodies, such as OKT4 and OKT8, which are now available and which specifically recognise helper and suppressor $\mathrm{T}$ cells respectively. A whole blood method including positive cytochemical exclusion of monocytes or the application of cytofluorometry to whole blood is also desirable. It is, however, worth noting that in disease states, unlike the normal situation, there may be a significant proportion of $T$ cells which bind both OKT4 and OKT8. ${ }^{41}$
We thank the Leukaemia Research Fund and Fisons Ltd, Pharmaceutical Division, for support, Dr H J F Hodgson for permission to study his patients, Dr P $N$ Maton for calculation of the Crohn's disease activity index in some patients, and Miss Joan Robins for expert secretarial assistance.

\section{References}

1 Meuwissen SGM, Feltkamp-Vroom TM, Zeijlemaker WP, Schellekens PTA, Brutel de la Riviere A, Tytgat GN. Crohn's disease, clinical activity and cellular immunity. In: Weterman IT, Pena AS, Booth CC, eds. The management of Crohn's disease. Amsterdam, London: Excerpta Medica, 1976: 121-7.

2 Morson BC. Rectal biopsy in inflammatory bowel disease. N Engl J Med 1972; 287: 1337-9.

3 Blackburn G, Hadfield G, Hunt AH. Regional ileitis. St Bart Hosp Rev 1939; 72: 181-224.

4 Phear DN. The relationship between regional enteritis and sarcoidosis. Lancet 1958; 2: 1250-1.

5 Binder HJ, Spiro HM, Meyer WR Jr. Delayed hypersensitivity in regional enteritis and ulcerative colitis. Am J Dig Dis 1966; 11: 572-4.

6 Verrier-Jones J, Housley J, Ashurst PM, Hawkins CF. Development of delayed hypersensitivity to DNCB in patients with Crohn's disease. Gut 1969; 10: 52-6.

7 Walker JG, Greaves MF. Delayed hypersensitivity and lymphocyte transformation in Crohn's disease and protocolitis. Gut 1969; 10: 414.

8 Parent K, Barret J, Wilson ID. Investigation of the pathogenic mechanisms in regional enteritis with in 
vitro lymphocyte cultures. Gastroenterology 1971; 61: 431-9.

9 Ropke C. Lymphocyte transformation and delayed hypersensitivity in Crohn's disease. Scand J Gastroenterol 1972; 7: 671-7.

10 Aas J, Huizenga KA, Newcomer AD, Shorter RG. Inflammatory bowel disease: lymphocyte responses to non-specific stimulation in vitro. Scand J Gastroenterol 1972; 7: 299-303.

11 Sachar DB, Taub RN, Brown SM, Present DH, Korelitz BI, Janowitz HD. Impaired lymphocyte responsiveness in inflammatory bowel disease. Gastroenterology 1973; 64: 203-9.

12 Asquith P, Kraft S, Rothberg R. Lymphocyte responses to non specific mitogens in inflammatory bowel disease. Gastroenterology 1973; 65: 1-7.

13 Strickland RG, Korsmeyer S, Soltis PD, Wilson ID, Williams RC. Peripheral blood T and B cells in chronic inflammatory bowel disease. Gastroenterology 1974; 67: $569-77$.

14 Bird AG, Britton S. No evidence for decreased lymphocyte reactivity in Crohn's disease. Gastroenterology 1974; 67: 926-32.

15 Richens ER, Williams MJ, Gough KR, Ancill RJ. Mixed lymphocyte reaction as a measure of immunological competence of lymphocytes from patients with Crohn's disease. Gut 1974; 15: 24-8.

16 Bolton PM, James SL, Newcombe RG, Whitehead RH, Hughes LE. The immune competence of patients with inflammatory bowel disease. Gut 1974; 15: 213-9.

17 MacLaurin BP, Cooke WT, Ling NR. Impaired lymphocyte reactivity against tumour cells in patients with Crohn's disease. Gut 1971; 12: 794-800.

18 Meuwissen SGM, Schellekens A, Huismans L, Tytgat GN. Impaired anamnestic cellular immune response in patients with Crohn's disease. Gut 1975; 16: 854-60.

19 Sachar DB, Taub RN, Ramachander K, Meyers S, Forman SP, Douglas SD, Janowitz HD. T and B lymphocytes and cutaneous anergy in inflammatory bowel disease. Ann NY Acad Sci 1976; 278: 565-73.

20 Meyers A, Sachar, DB, Taub RN, Janowitz HD. Anergy to dinitrochlorobenzene and depression of $\mathrm{T}$ lymphocytes in Crohn's disease and ulcerative colitis. Gut 1976; 17: 911-5.

21 Thayer WR, Charland C, Field CE. Subpopulations of circulating white blood cells in inflammatory bowel disease. Gastroenterology 1976; 71: 379-84.

22 Hodgson HJF, Wands JR, Isslebacher KJ. Decreased suppressor cell activity in inflammatory bowel disease. Clin Exp Immunol 1978; 32: 451-8.

23 Auer IO, Gotz S, Siemer E, Malchow H, Ehms H. Immune status in Crohn's disease: peripheral blood B lymphocytes enumerated by means of $F\left(a^{\prime}\right)_{2}$ antibody fragments, null and $T$ lymphocytes. Gut 1979; 20: 261-8.

24 Lyanga JJ, Davis P, Thomson BR. In vitro testing of immunoresponsiveness in patients with inflammatory bowel disease: prevalence and relationship to disease activity immunoresponsiveness in inflammatory bowel disease. Clin Exp Immunol 1979; 37: 120-5.

25 Victorino RMM, Hodgson HJF. Alteration in $T$ lymphocyte subpopulations in inflammatory bowel disease. Clin Exp Immunol 1980; 41: 156-65.

26 Brown G, Greaves MF. Enumeration of absolute numbers of $\mathrm{T}$ and $\mathrm{B}$ lymphocytes in human blood. Scand J Immunol 1974; 3: 161-72.

27 Pepys MB, Sategna-Guidetti C, Mirjah DD, Wansbrough-Jones MH, Dash AC. Enumeration of immunoglobulin-bearing lymphocytes in whole peripheral blood. Clin Exp Immunol 1976; 26: 91-4.

28 Pepys MB. Characterisation and enumeration of lymphocyte populations in whole human peripheral blood. In: Bloom BR, David JR, eds. In-vitro methods in cell-mediated and tumour immunity. New York: Academic Press, 1976: 197-202.

29 Druguet M, Pepys MB. Enumeration of lymphocyte populations in whole peripheral blood with alkaline phosphatase labelled reagents: a method for routine clinical use. Clin Exp Immunol 1977; 29: 162-7.

30 Pepys EO, Pepys MB. Enumeration in whole peripheral blood of lymphocytes bearing receptors for $\mathrm{Fc}(\gamma)$ and $\mathrm{C} 3 \mathrm{~b}$ using alkaline phosphatase labelled reagents. J Immunol Methods 1980; 32: 305-14.

31 Pepys EO, Tennent GA, Pepys MB. Enumeration of T and $B$ lymphocytes in whole peripheral blood: absence of a null cell population. Clin Exp Immunol 1981; 46: $229-34$.

32 Haegert DG, Coombs RRA. Do human B and null lymphocytes form a single immunoglobulin-bearing population? Lancet 1979; 2: 1051-3.

33 Lockhart-Mummery HE, Morson BC. Crohn's disease (regional enteritis) of the large intestine and its distinction from ulcerative colitis. Gut 1960; 1: 87-105.

34 Lockhart-Mummery HE, Morson BC. Crohn's disease of the large intestine. Gut 1964; 5: 493-509.

35 Best WR, Becktel JM, Singleton JW. Rederived values of the eight coefficients of the Crohn's disease activity index (CDAI). Gastroenterology 1979; 77: 843-6.

36 Pepys MB, Druguet M, Klass HJ, Dash AC, Mirjah DD, Petrie A. Immunological studies in inflammatory bowel disease. In: Knight $J$, Porter $R$, eds. Immunology of the gut. Amsterdam: Excerpta Medica, 1977: 283-304.

37 Pepys MB, Dash AC, Markham RE, Thomas HC, Williams BD, Petrie A. Comparative clinical study of protein SAP (amyloid P component) and C-reactive protein in serum. Clin Exp Immunol 1978; 32: 119-24.

38 Rheinherz EL, Kung PC, Goldstein G, Schlossman SF. A monoclonal antibody with selective reactivity with functionally mature human thymocytes and all peripheral human $T$ cells. J Immunol 1979; 123: 1312-7.

39 Moretta L, Mirgasi MC, Moretta A, Haynes BF, Fauci AS. $T$ cells Fc receptors as markers of functional human lymphocyte subsets. In: Fougereau M, Dausset J, eds. Immunology 80. London: Academic Press, 1980: 223-38.

40 Rheinherz EL, Moretta L, Roper M, Breard JM, Mirgasi MC, Cooper MD, Schlossman SF. Human T lymphocyte subpopulations defined by Fc receptors and monoclonal antibodies. J Exp Med 1980; 151: 969-74.

41 Bach MAA, Bach J-F. The use of monoclonal anti-T cell antibodies to study $T$ cell imbalances in disease. Clin Exp Immunol 1981; 45: 449-56. 